CHAPTER I

\title{
Introduction: Region, Repertoire, and Genre
}

Two vignettes from my earliest fieldwork in the Chhattisgarh region of middle India stand out as interactions that set into play what became the central questions of this study. I spent the first month on the field visiting villages on the Phuljhar borderlands of Chhattisgarh in search of a fieldwork base. Realizing not all villages would be "equal" in the number of performance genres available, the festivals celebrated, and the castes represented, I planned to ask for general performance repertoires by gender, caste, and village and take these into consideration in my choice. ${ }^{1}$ Seated in the courtyard of a high-caste, Aghariya Chhattisgarhi village headman (gauntiy $\bar{a}$ ) in the first village I visited in September I980, surrounded by a large crowd of household and neighborhood women, I tried out my survey strategy by rather simplistically asking "what kinds of songs they sang" (using the Hindi words git and gāna ); drawing blank stares, I tried again, this time being more specific by asking if they sang songs at their weddings. Their categorical answer of "no" was surprising, since I had found numerous appearances of women's wedding songs ( $v i \bar{i} \bar{g} \bar{i} t)$ in printed collections of Chhattisgarhi folklore available in the library at the University of Wisconsin. It was only several days later that I began to realize that Chhattisgarhi usage of the word ganna (to sing), without being placed in relationship to a particular genre of song (such as viha $g \bar{t}$ ), is limited to male, professional singing-and this the women did not do. I realized that while I knew the Chhattisgarhi terms for

${ }^{1}$ I was still naïve at that point about the weight in making that decision that would be carried by more logistical practicalities such as finding a household in which there would be an empty corner for an extra bed, typing table, and tin trunk. 
"song" and "to sing," I did not know the indigenous rules of usage for these terms; inappropriate usage had resulted in miscommunication. I did not yet know the indigenous "ways of talking" about folklore, genre, and performance.

The second vignette also began on this initial tour of potential field sites, but it reached closure only several months later. This time, the village was a primarily Oriya-speaking one. I had learned by now that I needed to be more specific in my enquiries about repertoire, so I asked the women of a high-caste Kolta family whether they sang vih $\bar{a}$ git at their weddings. They enthusiastically assured me that they did: "Of course we sing them at our [hamar] weddings." This was the village in which I eventually chose to live for four months before moving to the town of Dhamtari in Chhattisgarh's heartland. I had already left, however, when the wedding season began five months later; and I traveled six hours by bus to return to the village for the wedding of the daughter of this same household. After a full day of ritual, beginning with the turmeric anointing (haldi lagānā) of the bride and now close to ending with her vida (ritual of farewell, sending her to her in-laws), there had not yet been a single women's song. I reminded my friends of their earlier assertion, with what I'm sure was a note of exasperation, "I thought you said that you sang $v i \bar{i} \bar{a}$ git at your weddings." They laughed, and one explained, "When we said we, we didn't mean our caste, we meant Oriya women."

This initially frustrating fieldwork experience images the complex ways in which folklore genres help to identify, delineate and give identity to folklore groups and communities. The assertion that "we sing at our weddings" was made to me as a newcomer to the region and an outsider to the village. The speaker was identifying on a general level with the Oriyaspeaking community of Chhattisgarh, even though it is women from àdivāsi (tribal) castes, and not her own, that sing these wedding songs. Close to five months later, the same speaker found it humorous that I had interpreted the "we" so specifically, by caste; however, it is probable that she would not have made such a broad identification between community and genre when speaking to me after I had lived in that same village for several months and had become more familiar with the indigenous terminologies of the system of Chhattisgarhi genres and their rules of usage.

Over the initial weeks of looking for a village in which to live and the months that followed during which I visited many other villages, my questioning regarding performance repertoires became more refined. I began to frame the questions with a phrase I had heard in many of the initial responses I had received, "Here in Chhattisgarh." I would follow this with a question such as, "What kinds of festivals do you celebrate/observe (kyā kyā tyohār 
manäte hai)?" or I would give specific examples of the kinds of performance genres with which I had heard other villagers respond, such as candaini or the sua năc. A core repertoire of genres gradually emerged from the varied responses, one that was repeatedly identified with the region Chhattisgarh. If conversations continued further or if we started to talk more specifically about one of the individual genres, the genres often began to be identified with smaller social groups (according to caste, gender, or age). The Oriya Kolta women mentioned above were not alone in identifying with Chhattisgarhi or Oriya genres on a sliding scale of inclusive identity, depending on the context and identities of conversational partners.

The focus of my study consolidated around this indigenously identified repertoire of Chhattisgarhi performance genres. I became interested in the repertoire as a system of genres, in its boundaries, terminologies, and internal organizing principles. As I listened to what performers and audiences talked about most when discussing or commenting on particular genres and performances, it gradually became apparent that a central organizing principle of the repertoire is the social identity of those to whom a genre "belongs"; genres are categorized on the basis of this social identity more commonly than on the basis of form or thematic content. I have used these principles of indigenous repertoire and genre as an interpretive frame through which to enter the analyses of six representative genres performed in the central plains of Chhattisgarh and in the border region of Phuljhar.

The first three genres considered in this book are female ritual traditions, and the last three are male-performed narrative genres in which female characters are central. The bounded regional repertoire of which these are a part presents to us a strikingly female-centered world. Female performers and/or characters are active and articulate and frequently challenge or defy brahminic (frequently male) expectations of gender. In this performance world, men, too, confound gender roles: a male storyteller assumes a mother's voice in noticing the subtle early signs of her daughter's pregnancy; a male character takes on female disguise to protect himself in an all-female kingdom in which he is seemingly helpless; men appropriate a particular female genre to displace its defiant voice. This play of gender and genre in the Chhattisgarhi repertoire contributes to the construction of a particular regional cultural ethos and is key to its understanding.

\section{Chhattisgarh as a Geographic and Historical Region}

Modern Chhattisgarh is a geographic, historical, cultural, and linguistically defined region of eastern Madhya Pradesh, bordering Orissa, made up 


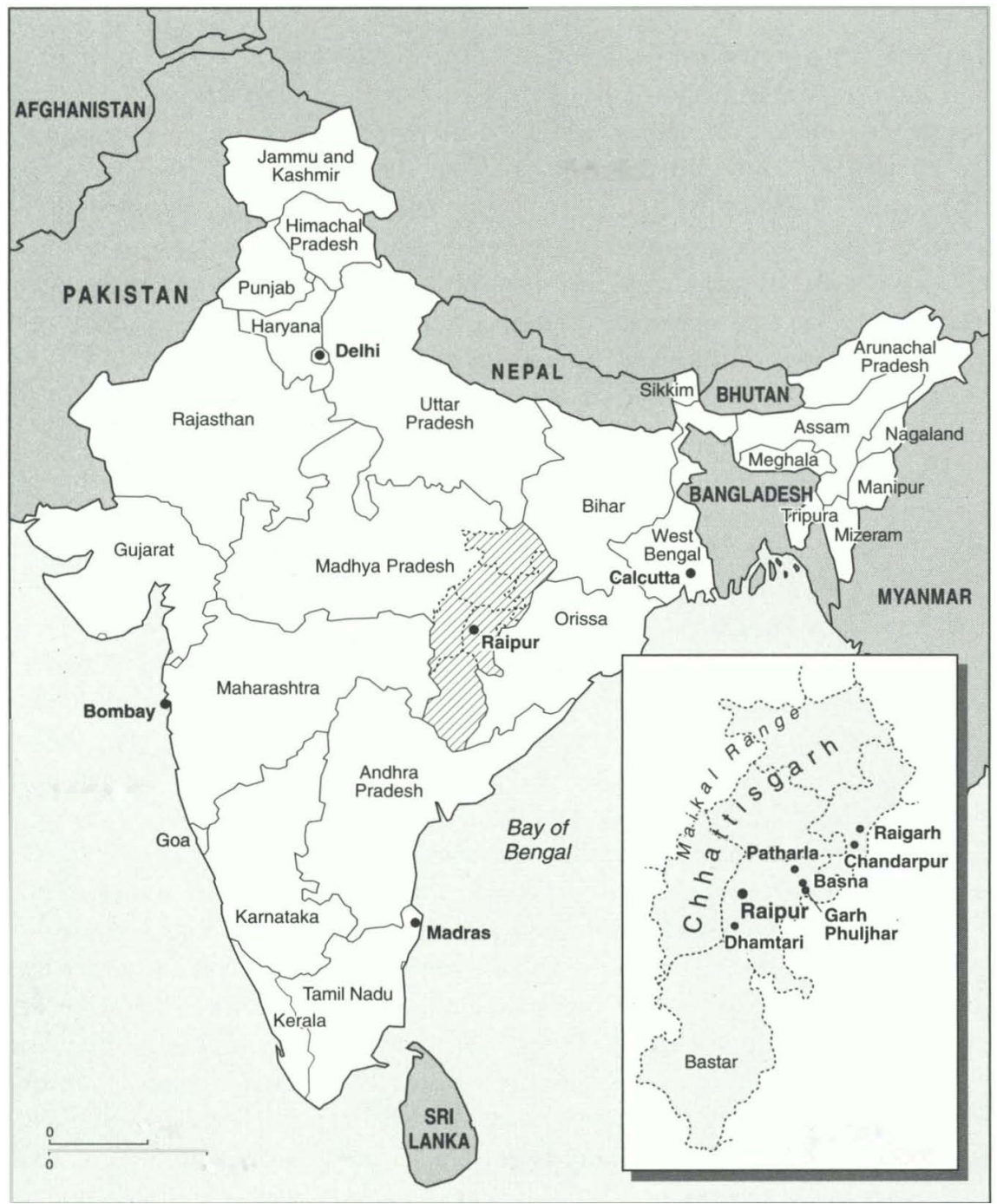

Map 1. Chhattisgarh, Madhya Pradesh

of five districts. ${ }^{2}$ My own fieldwork was confined to Raipur District, in two distinct areas, one in the district's heartland and one on the periphery of both

2 These include Bilaspur, Surguja, Raigarh, Durg, and Raipur Districts. Bastar District is sometimes added as a sixth district of Chhattisgarh but has always retained a distinct identity and is more often excluded from the Chhattisgarhi districts because of its unique history and its more purely tribal population. 
the district and the region. Chhattisgarh consists of a large rice-growing plain, watered by the Mahanadi River and its tributaries, and the surrounding hill regions. To the northwest, the plain is bounded by the Maikal Hills, to the west by the Satpura mountain range, to the south by the hills marking the border of Bastar, and to the east by the hills separating Chhattisgarh from the province of Orissa. Historically, the geographic barrier of these hills has helped to isolate Chhattisgarh from surrounding regions and has been a contributing factor in the development of Chhattisgarh as a politically and historically defined region. Obviously, the strength of these hills as boundaries has been minimized by modern transportation systems and popularmedia channels such as radio, television, and film.

The Chhattisgarhi plain is a heavily populated, fertile agricultural area. The construction of a canal system from the Mahanadi River has made possible double rice crops in many parts of the plain. The boundary hill areas are both less populated and less fertile, the original home of much of the tribal population of Chhattisgarh. Today, however, a high percentage of the tribal population lives in the plain and has been integrated into the local Hindu caste hierarchy, as independent castes.

Before Indian independence in 1947, the plains and hills were also differentiated on the basis of land revenue and tenure into the khals $\bar{a}$ and zamindāri systems, respectively (Weaver I968:I53-I55). Under the khals $\bar{a}$ system, every village and its surrounding land was controlled by a mālguzār, who was responsible to the central ruling power. The zamindàri estates of the hill and forest regions were often as large as several hundred square miles and incorporated many villages. Each village was under the administrative power of a thekedar, who was responsible to the zamindär, who in turn paid revenues to the central power. The zamindär were often quasi-independent from the central ruling power and were themselves called kings (rajja). In I95 I the khalsā and zamindāri systems were merged for purposes of revenue administration (Verma 1973:4).

The early history of Chhattisgarh reveals a characteristic pattern of minor kingdoms whose kings were often from junior branches of major ruling families to the north but who had gained semi-independence from centers of ruling power, partly because of the geographic distance from those centers. This history indicates that, although centrally located in middle India, Chhattisgarh was under primarily northern political influence, rather than under the domain of southern ruling powers.

The name Chhattisgarh is popularly believed to mean "the land of thirtysix forts," chattis meaning "thirty-six". and garh meaning "fort." A. E. Nelson finds inscriptional support for this popular conception in a Khalari inscription that states that King Simhana, the second ruler of the junior Ratanpur 
branch, conquered the eighteen forts of the enemy. Presumably, this was half the territory ruled by the Haihayas in Daksina Kosala; therefore, the entire territory would have included thirty-six forts. But Nelson acknowledges that in all probability this was not the original derivation of the name, for the name Chhattisgarh does not appear in a single inscription. He believes the more likely derivation is from "Chedisgarh," or "the forts of the Chedi lords," since the Haihaya rulers were a younger branch of the Chedi dynasty who continued to be proud of the name (I909:49).

C. U. Wills has reconstructed, on the basis of the scant evidence left after the Maratha invasion, a Haihaya administrative political organization that also accounts for the concept of thirty-six forts (I919:197-262). He speculates that the system was five-tiered, beginning with the smallest unit of the village. Twelve villages formed what was called a barhon, derived from the Chhattisgarhi word for "twelve." Seven barhọon formed a caurāsī or garh (caurāsì means "eighty-four"; every garh or caurāsī consisted of eighty-four villages). The next tier was the northern and southern branches of the Ratanpur dynasty, each ruling over eighteen garh. Finally, the entire kingdom would have consisted of thirty-six forts under the dominion of the senior ruling family at Ratanpur. Wills contends that while the precise numbers were probably more theoretical than actual, these named administrative units were functional during the Haihaya rule of the region from the eleventh to the eighteenth century. What is most significant for our purposes, however, is the concept of thirty-six forts as an important indigenous characterization of the region, although not all are historically documented and rarely can many (or even most) of them be named by local inhabitants.

\section{Chhattisgarh as a Linguistic Area}

Language is perhaps the most tangible identity marker of the region. In I90I, 85 percent of the population of Raipur District claimed the dialect of Chhattisgarhi to be their mother tongue. By the I96I census, that percentage had decreased to 54.06 percent, with 3 I 6 percent citing Hindi (Verma I973:IOI). Most of the Hindi claims came from urban areas, however, with the majority of the rural population maintaining a Chhattisgarhi identification. Oriya was the language with the next highest percentage of mothertongue speakers in Raipur District, 8.83 percent in $196 \mathrm{I}$, a number that has continued to increase in recent years as more and more day laborers and household workers have been imported from Orissa.

Chhattisgarhi belongs to the eastern Hindi language branch, along with the dialects of Awadhi and Bagheli. One primary distinguishing feature of 
these eastern dialects is the verbal past tense being formed with the ending is.

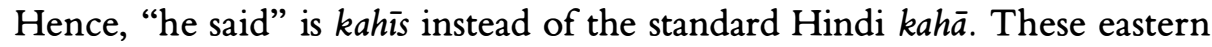
dialects also use $o$ instead of $e$ for the genitive form of personal pronouns: mor and tor for "mine" and "yours" instead of standard Hindi merā and terā. Perhaps because of its geographic isolation, Chhattisgarhi has also developed some characteristics unique from Awadhi and Bagheli. For example, the plural is formed with the suffix man: laikaman, "the boys"; the instrumental is formed with the suffix an: bhükhan, "with hunger"; and when a postposition follows a noun, the noun does not decline as it does in Hindi: laikaman ke, "belonging to the boys"; laika ke, "belonging to the boy." Further, no difference exists in the conjugation of Chhattisgarhi transitive and intransitive verbs in the past tense, that is, the Hindi ne following the subject of a transitive verb in Hindi is lost. Finally, few Chhattisgarhi speakers use feminine verbal forms.

Language is also a primary defining feature of the Phuljhar subregion on the borders of Chhattisgarh and Orissa, where I conducted my first four months of fieldwork. That is, Phuljhar is said to be that place where both Oriya and lariy $\bar{a}$ (that form of Chhattisgarhi directly influenced by Oriya) are spoken. Surely other linguistic and cultural crossroads, similar to Phuljhar, exist on other of Chhattisgarh's borders.

When I began to read about Chhattisgarhi as a linguistic dialect and returned to the region as an adult, I found some justification for what had otherwise seemed like arbitrary grammatical "mistakes" I made (such as dropping both the use of feminine endings and the use of $n e$ with the past tense of transitive verbs) and my seemingly idiosyncratic vocabulary usage in Hindi classes at the University of Wisconsin. ${ }^{3}$ I grew up speaking colloquial Hindi, first in Chhattisgarh and then in the foothills of the Himalayas where I spent nine months each year in boarding school; I remained functionally "nonliterate," however, until I began graduate school and studied Hindi formally for four years. I found that when I began my fieldwork in Chhattisgarh, I reverted to many old childhood patterns of dehātī (village) Hindi, which seemed to be more easily understood (or at least created fewer barriers) than what my Chhattisgarhi friends called the suddh (pure) Hindi. When I lived in an Oriya-speaking village in Phuljhar, I spoke Hindi with Oriya intonations, incorporating many Oriya vocabulary items, and was easily understood; likewise, I had few problems understanding everyday

${ }^{3}$ I remember feeling both confused and a little humiliated when the first-year Hindi teacher asked me during the first week of classes where I had learned my Hindi, saying I sounded "just like a servant." See Kavyopadhyaya 1890 for the most complete Chhattisgarhi grammar I have found available in English, one that includes samples of several Chhattisgarhi folk texts. 
Oriya conversations, which, in this area, are heavily influenced by Hindi and Chhattisgarhi.

\section{Chhattisgarh as a Cultural Region}

Just as important as geographic, historical, and linguistic factors to the definition of Chhattisgarh are cultural characteristics considered by its residents to be unique to the region. These include dress, jewelry, social institutions such as ritualized friendships, local festivals, and both verbal and nonverbal folklore traditions. Other social and religious institutions and festivals that are, in fact, pan-Indian are also frequently identified as "Chhattisgarhi" or are associated with the region through a phrase such as "here in Chhattisgarh," as if they may not exist outside the region at all. For example, an elderly woman prefaced her question to me regarding my jāti (caste) with, "Here in our Chhattisgarh, we follow the jāti system [ jāti mānte hai]."

A major factor contributing to this Chhattisgarhi cultural ethos is the high percentage of tribal ( $\bar{a}$ divass $\vec{i}$ ) population (I 5.6 percent in Raipur District in the I96I census); scheduled castes formed 14.94 percent of the population in this same census. ${ }^{4}$ Members of these tribal castes living on the Chhattisgarhi plain are now mostly cultivators or agricultural laborers, have acquired caste attributes, and have been integrated into the local caste hierarchy. ${ }^{5}$ They have adopted many pan-Indian Hindu practices, including the worship of major Sanskritic deities and celebration of pan-Indian festivals such as holi, daśharā, and śivrātri. Nevertheless, members of the àdivāsi population have also retained many of their own traditions, including certain marriage practices, jewelry and tattooing traditions, festivals, and verbal and material folklore. This population has had a strong impact on the wider Chhattisgarhi cultural ethos and sense of identity. Both àdivāsī and non-ādivāsì inhabitants of Chhattisgarh identify $\bar{a}$ divāsi traditions more than any others as being uniquely "Chhattisgarhi," whether or not they directly participate in them. A lecturer of Hindi literature at a community college in Dhamtari went so far as to say that only ádivāsi traditions can be called truly Chhattisgarhi; he asserted that all others are imports from the Hindi-speaking north (Narayanlal Parmar, I98 I, oral communication).

For someone familiar with north Indian (particularly, those of the Gangetic plain) social patterns and practices, the status and role of women in

4 The principal scheduled tribes of Raipur District are the Gond, Kawar, Binjhwar, Sawar, Halba, Bhunjia, and Kamar (Verma I973: I I 4-I I 5).

${ }^{5}$ See Bailey 1960 for a fuller discussion of this process. 
Chhattisgarh is particularly striking, differing even from that of women in central Madhya Pradesh. ${ }^{6}$ Increased freedom and status are most noticeable in the absence of strict physical veiling or purdah ( pardā) and face covering ( ghünghaț); these are generally not observed except among wealthy members of the highest castes (whose families are/were most often immigrants into Chhattisgarh). The physical seclusion of women that coincides with veiling is also practiced much less than it is by north Indian brides in their villages of marriage (sasurāl).

Although the majority of Chhattisgarhi women do not observe purdah per se, they do differentiate between public and household space and hold an ideal that women should not spend any more time than necessary in public space. So that even though many lower-caste women work in construction and road building, transplanting and harvesting rice, and selling vegetables and other goods in the bazaars, for example, they do not have freedom available to men of "loitering" unnecessarily in public spaces such as tea stalls, bus stands, or bazaars. ${ }^{7}$ In the Oriya villages of Phuljhar, too, women observe a certain degree of conceptual purdah by not lingering in public, male space. In the village in which I lived, for example, women were quite free to walk (most often in pairs) on the village main street or to the village tank to bathe and wash clothes-and often visited several friends on the way - as long as they had some destination and purpose in their outings. ${ }^{8}$

The greater degree of freedom and the associated perception of greater status of Chhattisgarhi women in comparison with their northern sisters may be related to the influence of the $\bar{a}$ divāsi population and both the higher percentage of female labor participation and the female-to-male sex ratio in Chhattisgarh (Dange I973). In a I98 I study, Barbara Miller mapped out, by district, the percentage of working females in rural India according to the statistics of the 196 I census. Chhattisgarh stands out on her map as one of the few regions in which the percentage is as high as $85-100$ percent (see also Verma 1973:91). She suggests that in those regions where a high percentage

${ }^{6}$ For a comparison of women's roles, rituals, and status in north and central India (west of Chhattisgarh), see Jacobson and Wadley 1977.

${ }^{7}$ See Sharma 1980 for a discussion of the differentiation between public and private space for women in South Asia.

${ }^{8}$ I myself felt the boundaries of this freedom when I had a latrine and bathstall built onto the small house in which I lived at the edge of the village. I sorely missed the built-in daily contact with many of the village women when I stopped bathing in the river, and I soon gave up the indoor bathing to rejoin them. One evening, a close friend of my hostess came by our house on her way to "the fields" and asked her if she would accompany her, saying that she missed her company and the chance to talk. They returned a half hourlater, my hostess having been filled in on some significant village "gossip." Thus, while indoor plumbing may simplify a village woman's life, it may also isolate her from other women. 
of women are included in the work force, primarily rice-growing areas, there will be a more balanced sex ratio than in those areas where the percentage is lower, such as the wheat-growing areas of the north and northwest. Rice is a labor-intensive crop in whose cultivation women participate in both the transplanting and harvesting phases, whereas wheat growing requires less labor. Census statistics confirm Miller's hypothesis. Since first reported in I90I, a preponderance of females to males has existed in Raipur District. The I96I census reports I,037 females for every I,000 males; a similarly high sex ratio was maintained in the I97I census report. This statistic stands out as a unique regional feature when compared with that for the rest of Madhya Pradesh, whose overall ratio was 953:1,000, and the allIndia ratio of 943.7: I,000. In I96I, the province of Punjab in northwest India had the lowest female-to-male ratio in the country at 864.3:1,000 (Miller I98I:I 6 ); this province also has a low percentage of females in the labor force. In those areas where women are active participants in the labor force outside the household, the birth of a daughter is not considered the high liability that it is in those areas where women's labor is primarily limited to the household. In the former, bride-price rather than dowry is often common practice, as is true among the lower and ádivāsi castes of Chhattisgarh.

There are, of course, limitations in relying too heavily on these kinds of census and survey-based statistics, not the least of which is the problem of definition of "female labor participation," but they do give us some basis on which to draw a number of generalizations about the comparative position of women in various regions of India. According to these, Chhattisgarh seems to fit more closely with the south Indian pattern of rice-cultivating areas, where the percentage of female labor participation is high, rather than with the wheat-growing areas of the north. ${ }^{9}$ A daughter becomes more economically valuable in these regions and therefore may hold a position of higher status than her sisters in the north. Further, where women are active in the public work force, in agriculture, construction, and so forth, physical purdah is more difficult to maintain.

The relative freedom and independence of women in Chhattisgarh is reflected in such social/cultural practices as divorce and remarriage, as well

9 This supports the suggestion that a northeast-southwest axis is perhaps more reflective of pan-Indian cultural patterns than the more frequently articulated cultural, geographic axis between north and south India. The latter more precisely refers to the northern Gangetic plain and Dravidian-speaking south; the placement of Gujarat, Maharastra, Orissa, and parts of Madhya Pradesh (including Chhattisgarh) is ambiguous in this divide. See Sopher I 980 for an extended discussion of the geographic patterning of culture, including Bernard Cohn's proposal of an east-west cultural axis for India. 
as in the frequency of bride-price instead of dowry among the lower castes. Although the high castes of Chhattisgarh do not favor these practices, they are permissible and common among such middle and low castes as the Teli, Kurmi, Rawat [Raut], Panka, Dhobi, Nai, Kewat, and àdivāsì castes (Verma I973:I2I). The census village survey of Bendri village in Raipur District reports that in practically all cases of separation and divorce in the village, it was the woman who left her husband rather than the other way around; and if she did return to her husband, there was little stigma attached to her for having lived with another man (Verma 1973:37). My experience in the Gond neighborhoods of Dhamtari in which I spent time supports these findings. In the several cases in which women had left their husbands to return to their maternal villages (maika) , although there was some neighborhood discussion about them, they were not stigmatized. In the chapters that follow, we will see that this relatively higher status of women in Chhattisgarh is reflected in the performance context and textual content of the folklore genres under consideration.

\section{Chhattisgarh as a Folklore Region}

In my conversations with male and female respondents from a wide spectrum of caste levels over the early months of my fieldwork, there gradually emerged a core repertoire of performance genres that was specifically identified as "Chhattisgarhi," a repertoire contributing to the perception of a unique regional cultural ethos. Audiences and performers articulated a relatively consistent listing of what belonged in this repertoire-what genres typified the region-even if they themselves did not participate in them directly as audience or performers. Among the genres most frequently mentioned were:

sua nāc the parrot dance; an ādivāsi female harvest dance and song tradition gaurā an àdivāsi festival celebrating the marriage of the god and goddess Shiva and Parvati (Gaura/Gauri)

bhojali a song and festival tradition celebrating ritual friendships and worshiping the goddess as wheat seedlings; observed by women only javāra a goddess festival similar to bhojali but celebrated by both men and women

băs git songs sung by the cowherding caste (Rauts) to the accompaniment of large bamboo flutes (băs, meaning "bamboo or flute")

rāut dohā couplets sung by Raut cowherders, often at the Raut festival of mātar dadariy $\bar{a}$ rhyming couplets sung primarily as field songs but also when walking to the bazaar and so on 
candain $\bar{i}$ the Chhattisgarhi regional epic

pandvān $\bar{i}$ a narrative genre based on episodes from the pan-Indian Mahabharata epic

Pan-Indian verbal traditions performed in Chhattisgarh primarily by castes relatively high in the social hierarchy are only rarely included in the "Chhattisgarhi repertoire." These traditions include the north and central Indian tradition of rāmlì $\bar{a}$ (dramas based on the pan-Indian Ramayana epic), vrat katha (narratives told at fasting rituals), kissa (mythological narratives not associated with specific rituals or festivals), and bhajan (religious devotional songs not associated with specific festivals). Also excluded from this indigenously articulated repertoire are, with perhaps the exception of dadariy $\bar{a}$ couplets, what I call "private" performance genres, such as nonprofessional, domestically performed folktales and lullabies, and genres embedded in everyday speech, such as jokes and proverbs. In a complete ethnography-ofspeaking analysis of the performance genres of a given village or region, one would include both pan-Indian and private performance traditions as part of the performance repertoire. However, members of the folklore communities in which I lived and traveled differentiated between a repertoire that characterized the region and the repertoire of genres performed in the region. This indigenous identification places the genres marked as "Chhattisgarhi" in a particular intertextual relationship within a bounded subset of the much wider, unnamed, unbounded repertoire that might be identified by a folklorist. So I begin by looking first within the "marked" repertoire identified by the folklore community itself as "Chhattisgarhi," asking what characterizes this repertoire.

\section{Phuljhar as a Subregion on the Boundaries}

I began the fieldwork on which this study is based by living in a village in a subregion of Chhattisgarh called Phuljhar, which lies on the boundaries between Chhattisgarh (Madhya Pradesh) and Orissa. Phuljhar is one of the oldest and largest former zamindān estates in the modern Raipur District of Chhattisgarh, reported in the 1909 Raipur District Gazetteer to have been ruled by the same Raj Gond family for twenty generations; ${ }^{10}$ the Phuljhar

10 "Gond" is a generic term describing a large group of unhomogeneous tribes living in middle India. "Raj Gonds" refers to those Gonds who were once traditional rulers in what has been called Gondwana. See Furer-Haimendorf and Furer-Haimendorf I 979, chapter I, "The Gonds in History and Literature," for an overview of the geographic spread and history of tribes that have been called Gonds. In contemporary Chhattisgarh, the term "Raj Gond" is 
zamindār was long recognized to be the head of the Raj Gonds (Nelson I 909:3 I9). Many of the thirty-six forts of Chhattisgarh that can be identified were the headquarters of large zamindāri, and Phuljhar is one of these. In what is now "jungle" near the town of Basna stand the ruins (which the villagers who showed me around said are 250 years old) of Garh Phuljhar. The headquarters of the Phuljhar zamindāri were moved from Garh Phuljhar to the town of Saraipali, where descendants of the former ruling family still live in a run-down palace.

Although former zamindāri estates such as Phuljhar are considered to be part of the region of Chhattisgarh, the larger ones have retained a separate identity as well. Even today, if asked where they are from, residents of modern Phuljhar frequently answer with the name of Phuljhar first, rather than Chhattisgarh. In fact, not all residents of Phuljhar want to be identified with Chhattisgarh. The zamindāri originally belonged to Sambalpur District to the east, in modern Orissa. In I 906 Sambalpur District was ceded to what was then Bengal Province, but the Phuljhar zamindāri was joined to Raipur District. Some Oriya speakers of Phuljhar still feel that the zamindāin should have remained part of Sambalpur District, hence modern Orissa province, partially so that they would benefit from the large Hirikud Dam that irrigates so much of Orissa immediately to their east. But because of current political boundaries and structures, residents of Phuljhar are drawn primarily to the city of Raipur to their west, rather than Sambalpur to the east, as an economic, legal, educational, and transportation center.

Phuljhar is more than an administrative unit, however; it is also a cultural and linguistic subregion. The name "Phuljhar" literally means "where flowers fall," deriving from the impression voiced by residents that flowering trees exist in the jungles of Phuljhar throughout all the seasons of the year. And, in fact, this borderland of Chhattisgarh is less heavily inhabited, more "jungly" than the Raipur plains, and lies in what are called the hills of Chhattisgarh. The most common characterization of Phuljhar by its inhabitants is that it is that part of Chhattisgarh where people speak both Oriya and a variant of the Chhattisgarhi dialect called lariya $\bar{a}$. Oriya is the dominant language of Phuljhar, but most Oriya castes speak, or at least understand, some form of Chhattisgarhi, and vice versa. One village headman called Phuljhar the "khicrin [literally, a cooked mixture of rice and lentils] of Orissa and Chhattisgarh."

As one might expect by observing the linguistic patterns of Phuljhar, the subregion's inhabitants also articulate a "khicrn" repertoire of performance

most frequently used to refer to landowning Gonds, who presumably were once "rulers" or zamindār of greater or lesser political domains. 


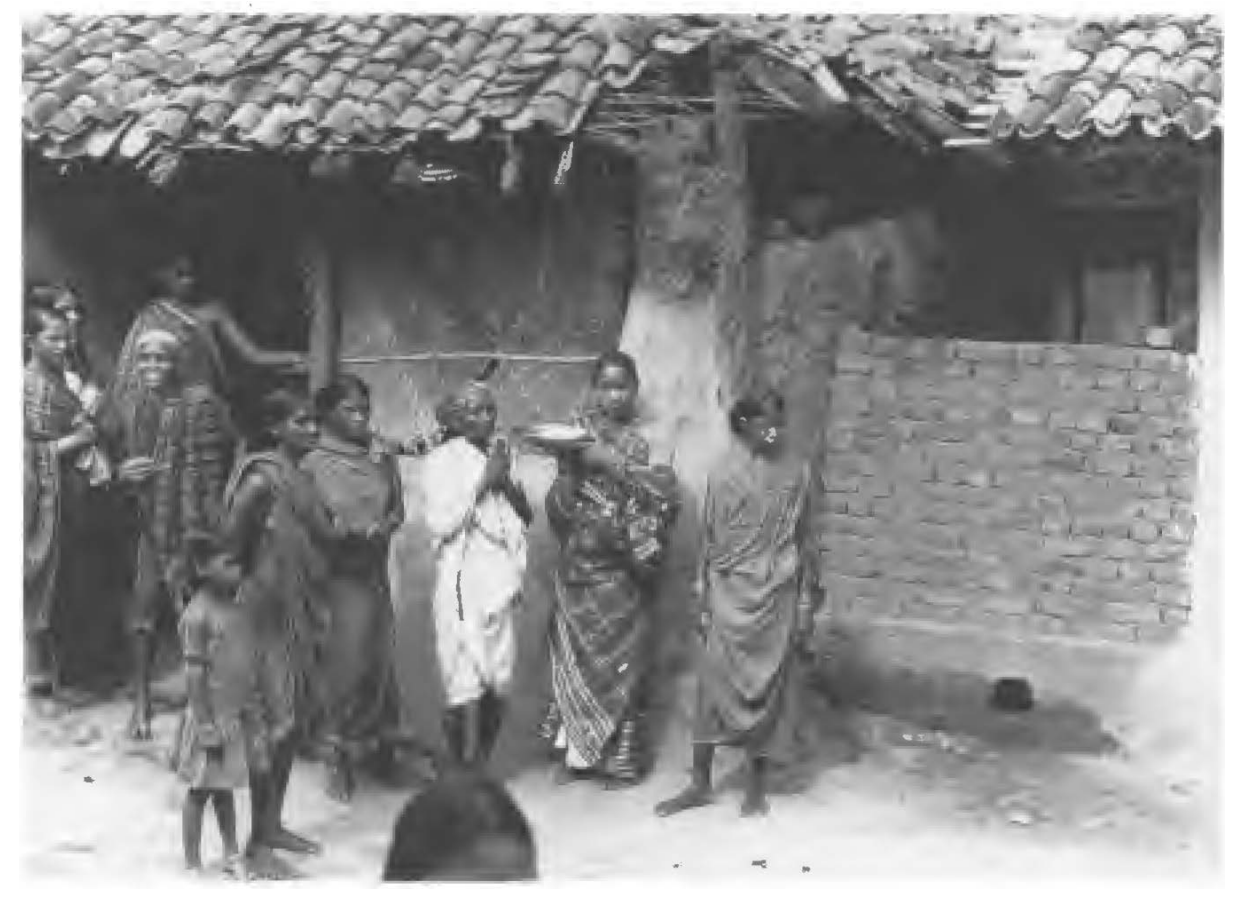

Village women of Phuljhar.

genres, drawing from both what is identified as the Chhattisgarhi repertoire and that identified as the Oriya repertoire. The Phuljhar repertoire includes suā nāc, bhojali, and gaurā (and, interestingly, leaves out the epic tradition of

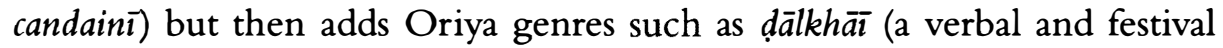
tradition of reversal for unmarried girls), homo (a girls' song-game tradition), the tradition of bähak performers (professional dancers-singers who perform at "each of the thirteen Oriya festivals"), and the festival of rath yatra (honoring the god Jagannath). Of significance to us is how the rules of usage change for a particular Chhattisgarhi genre (such as bhojali ) when performed within the context of the Phuljhar repertoire, on the regional boundaries.

When I began my fieldwork in Phuljhar, I was not fully aware of the complex ways in which the Oriya and Chhattisgarhi castes-their dialects and oral traditions-interacted. My choice of this area as a preliminary field site was more pragmatic: it is the area where I had lived as a child, my parents still lived there, and I had numerous contacts and friends in the area and access to transportation to remote villages. In retrospect, however, Phuljhar's location at the boundaries, and its characterization as a crossroads of linguistic and performance traditions, added a dimension to this study that would not have been available had I lived only in Chhattisgarh's heartland. To live 
on the periphery provided comparative materials that helped to delineate what I have called the Chhattisgarhi folklore region (communities sharing a repertoire or parts thereof) and the various folklore communities within that region (distinguished by the rules of usage for shared genres within the repertoire).

\section{Indigenous Genres and Repertoire}

While distinct, but overlapping, repertoires of genres can be identified for the Phuljhar borderland and central Raipur plains, the repertoires share key principles of genre identification and organization. That is, there is a Chhattisgarhi "way of talking" about performance, a system of indigenously articulated genres, that provides both us and indigenous audiences with frames for interpretation.

Influenced by the methodologies of the ethnography of speaking (Gumperz and Hymes 1972; Hymes I974a, I974b), performance-centeréd folklore scholars have reoriented the definitions of folklore genres from those of classificatory labels based primarily on form or content for the convenience of archivists and comparative folklorists to "orienting framework[s] for production and interpretation of discourse" (Bauman I992b:53). With this new perspective, genres become "practice-centered" categories, rather than "item-centered" (Bauman I992b:57) - active cultural categories, rather than static classificatory items. So conceived, genres are not objective categories but become "part of a politics of interpretation in which meaning and the authority to propose and ascribe categories is contested" (Shuman I 993: 7I). The boundaries and interpretations of such indigenous genres are flexible and shifting within changing historical and cultural contexts. A central task of the folklorist, then, becomes that of determining not only what the repertoire of available genres is within a particular culture or community and the indigenous categories and organization of that repertoire but also who is articulating these categories.

Dan Ben-Amos made a crucial distinction between analytic categories and ethnic genres (what I am calling indigenous genres) in an early but continuingly influential essay written in the late I960s and republished in Folklore Genres (1976). He distinguishes the terms as follows:

Whereas ethnic genres are cultural modes of communication, analytic categories are models for the organization of texts. Both constitute separate systems which should relate to each other as substantive matter to abstract models. Yet this relationship has not materialized.... We attempted to construct logical 
concepts which would have potential cross-cultural applications. . . In the process, however, we transformed traditional genres from cultural categories of communication into scientific concepts. . . a as if they were not dependent upon cultural expression and perception but autonomous entities which consisted of exclusive inherent qualities of their own. (2 I 5-2 I 6 )

The ethnic system of genres constitutes a grammar of folklore, a cultural affirmation of the communication rules that govern the expression of complex messages within the cultural context. (225)

Ben-Amos suggests that ethnic genres are distinguished from each other in paradigmatic relationship one to the other, often identifiable by sets of "contrastive attributes" (235), thereby affirming the importance of contextualizing individual genres with a system of genres and encouraging this as a direction for future folklore research. In the examples he explores in this essay, however, Ben-Amos looks primarily at the relationship between two contrastive genres rather than the larger repertoire of verbal folklore of which they are a part and the principles of its organization. ${ }^{11}$

Since the publication of this essay, most of the creative activity of folklore studies has centered on performative approaches to the study of individual genres, the interaction of verbal texts and performative contexts, and the emergent quality of performance, with less attention being paid to the context provided by the repertoire in which a particular genre is situated. However, a handful of excellent multigenre studies have sampled the variety of intertextual relationships between genres of a given repertoire. Gary Gossen has taken on perhaps the broadest study of a folklore system within a specific culture, that of the Chamula Indians in Mexico (1974). He elicited an indigenous taxonomy of folklore genres and searched for its organizing principles, which he found to be that of time and space. His interest was how the organization of genres reflects a worldview; he provides generalized descriptions of performers and performance context, with representative texts, rather than analyses of individual, situated performances. Another multigenre study, with a more specifically ethnography-of-speaking, linguistic approach, is Joel Sherzer's Kuna Ways of Speaking (1983). Charles Briggs juxtaposes a range of genres available in Mexicano verbal art (I988) to examine the differential roles of individual creativity and competence in the performance of individual genres. Richard Bauman has analyzed intertextuality on several levels, both in the relationships among several narrative

${ }^{11}$ See also Roger Abrahams and Richard Bauman's similar study of two contrastive genres, sensible speech and talking nonsense, in Vincentian speech taxonomy (I97I). 
genres in Texas (1986) and genres as they are embedded within other genres in the tradition of Icelandic legends of Kraftskald (I992a).

Within South Asian folklore scholarship, again, the number of multigenre studies are few (excepting collections of folklore "texts," such as those made by colonial folklorists). Susan Wadley (I975) published an early survey of the folklore repertoire of a single village community in north India in which she lists thirty-one indigenous categories of song. She suggests that the terminology for folklore genres tends to correlate with some aspect of their performance context, but she does not expand further on indigenous principles of their organization, for the purpose of the article is to provide a landscape of genres rather than their analysis. In her more recent work on the north Indian epic tradition of Dhola-Maru.(I99 I, 1989), Wadley approaches intertextuality between genres in a manner similar to that of Bauman's study of embedded genres. She has worked closely with an individual Dhola singer and has elicited interesting commentary about the ways in which he "constructs" a performance and uses embedded genres. She finds that Dhola singers incorporate numerous nonepic song styles to create the moods of the seasons or occasions in which those songs are traditionally performed.

Ethnomusicologist Edward Henry has also sampled a range of song traditions in his study of the north Indian Bhojpuri-speaking region (1988). Again, his purpose is to provide a landscape of musical genres and to generalize about the role of music in village life; he is less concerned with indigenous categories and repertoire and other elements of performance context. He draws generalizations of the general shape and "ground rules" of, for example, women's wedding rituals or the celebration of the festival of holi, against which the emergent nature of individual performances could be analyzed; but he himself does not follow this line of analysis.

Peter Claus has approached the issue of genre and intertextuality (1989) by examining performative variation of what he identifies as a single genre, that of the paddana multistory tradition of southwest India (Tulunad). The indigenous terminology paddana classifies "loosely connected" stories together, although their performance contexts and styles vary significantly. Claus calls these varying styles/contexts for the paddana "subgenres." $\mathrm{He}$ is interested in the covariation between the "story" and its variable social contexts of performance, concluding that "different versions serve to distinguish social groups and establish relations between them" (72). The theme of performance identifying and giving identity to social groups is also central to this study of Chhattisgarhi genres. Because the social identity of the performers of the different contexts/styles of paddana vary so significantly, it is likely that according to Chhattisgarhi principles of genre identification and 
organization, within this regional repertoire, they would be categorized as discrete genres (see Chapter 6 for a discussion regarding the candain $\bar{\imath}$ narrative as performed in the sua $n \bar{a} c$, where context supersedes narrative content to determine genre classification).

Finally, A. K. Ramanujan's I 986 essay “Two Realms of Kannada Folklore" encouraged South Asian folklorists to begin thinking about folklore repertoires as performative systems of meaning, in which each genre is related to and distinguished from other genres. He draws on an early Dravidian distinction between the paradigmatic categories of domestic (akam) and public (puram), a distinction of types articulated in commentary on early classical Tamil poetry, to look at the ways in which these contrastive settings are also relevant in Kannada folklore (particularly narrative). The categories help to distinguish contrasted pairs of folktales, myths, and ritual within the repertoire, distinctions that affect the performative text and style of each category.

\section{A Chhattisgarhi System of Genres}

In this study of Chhattisgarhi performance genres, I approach intertextuality-the play of genres-by seeking to understand principles of indigenous genre identification and organization within a marked repertoire. The specific ways in which the framework of genre and repertoire affects audience reception and interpretation of performance becomes apparent only in the juxtaposition of genres within the larger system. Consciously acknowledging "genre" as a frame for interpretation, then, I use these principles as entry into the analysis of individual performance traditions and specific performances of those genres. Although the categories through which I approach my analyses are based on indigenous principles of genre and repertoire, the analyses go beyond this entry and are not in any way "indigenous" themselves. Chhattisgarhi performers and audiences are much more articulate about the performance contexts ("exteriors," if you will) of their verbal and ritual folklore genres than about their textual "interiors." I have had several occasions to "try out" some of my conclusions in conversations with Chhattisgarhi friends and performers over the last few years; on the most part, they have been only vaguely interested in the implications of what they perceive to be quite obvious. As the female performer of what she framed as an explanatory narrative for the festival of dialkhāi (Chapter 3 ) said when I pressed her for further commentary, "Well, that's the story."

Indigenous genres are identified by a combination of formal, thematic, and contextual features (Ben-Amos I976:225), but the degree to which one 


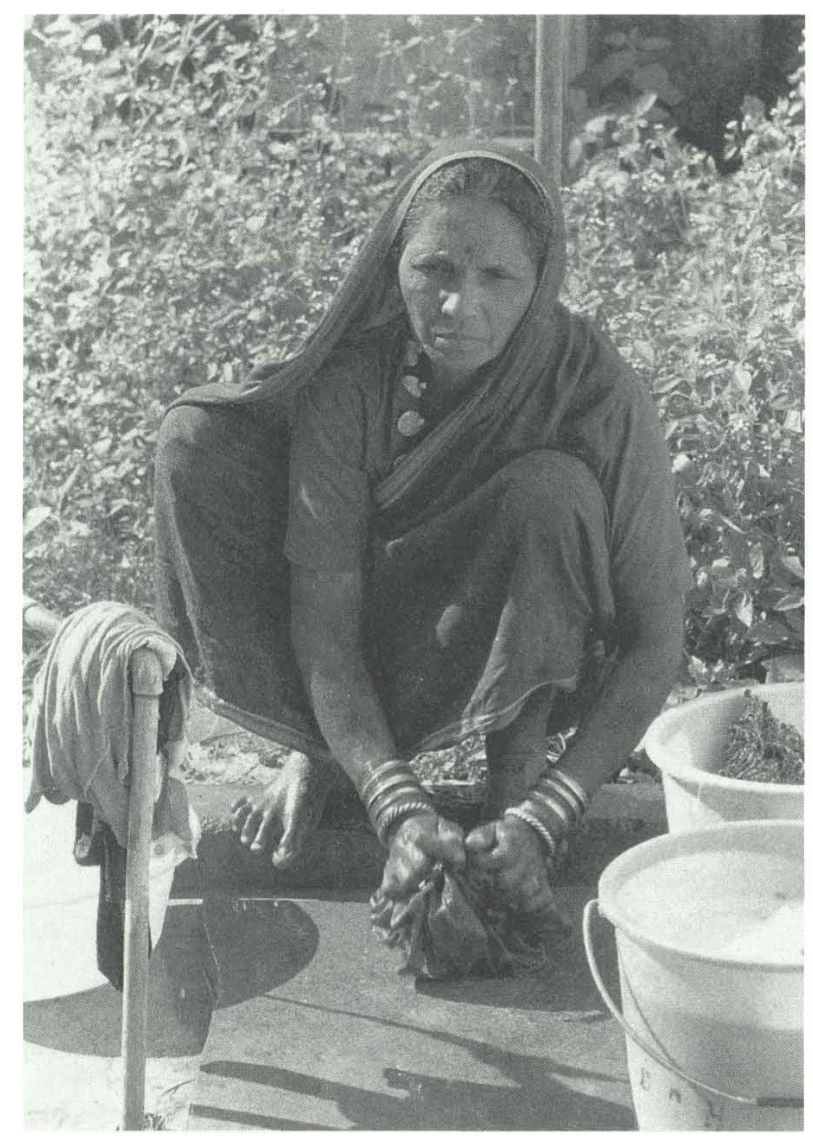

Chhattisgarhi woman of the Raipur plains.

or the other of these is foregrounded within a given cultural repertoire and individual genre varies significantly. Ben-Amos suggests that one entry into the criteria according to which genres are distinguished and associated is to look at their names, "which often reflect their symbolic value in the network of formal communication and their position in the cultural cognitive categories" (1976:235). Like the traditions named in Wadley's survey of the folklore of a north Indian village (I 975), many of the names of Chhattisgarhi verbal performance are contextually derived: the names of the festivals during which the song genres are sung, the terms of address for the performers, or the instruments used in performance. For example, bhojali are the songs sung during the festival of bhojalī, kathāni kūha literally means "storyteller;" and bas git are the songs of the bamboo flute. Several long narrative genres, on the 
other hand, such as the regional epic candain $\bar{i}$ and the local Mahabharata performance genre of pandvani, are named after their heroines and heroes. The names of these genres provide one frame for interpretation by indicating whether it is primarily the ritual and/or the social context, content, or form of the genre that is foregrounded in the reception of its performance.

In conversations with and informal commentaries by Chhattisgarhi villagers about particular genres, however, another principle of organization emerged within the repertoire which is not directly reflected in the terminology of particular genres but which provides the central frame of indigenous interpretation and basis for intertextuality: the association between genre and community. ${ }^{12}$ When members of Chhattisgarhi folklore communities voice associations between individual performance traditions within their repertoires, it is most often on the basis of this social organization and only secondarily by their ritual contexts. Although form is acknowledged by the usage of the Chhattisgarhi and Hindi words for song ( $g i t)$ and story (katha or kahāni $\bar{i}$ ), their usage is fluid, and strict boundaries between these formal categories are not maintained (both in performance itself or in the usage of these terms in everyday conversation). Further, genres to which the term git may be attached are not necessarily associated with one another (such as bhojali git and bãs gitt); and if they are, it is because of the social category into which they fall or the ritual contexts in which they are performed, not because of their form.

Thus, a verbal dueling game, identified by form as khel, and a festival-song genre, identified as git , performed by unmarried girls will be more frequently associated with each other than will song with song, or story with story, across social categories such as Oriya men, âdivāsi women, and unmarried girls. The regional epic candaini is performed in both a git (sung recitation) and nāca (dance-drama) style. Both, however, are categorized together simply as "candaini," unless the speaker wants to differentiate a particular performance. Candain $\bar{\imath} n \bar{a} c \bar{a}$ is rarely associated with other $n \bar{a} c \bar{a}$, and $n \bar{a} c \bar{a}$ troupes who perform candaini do not traditionally perform other nācā. Further, in local commentary and conversation, candain $\bar{i} \bar{i} t$ would not be associated with the git sung by unmarried girls in their formation of bhojali ritual friendships. In Chhattisgarhi language usage, the terms git and katha $/ k a h \bar{a} n \bar{\imath}$ have not traditionally indicated indigenous interpretive frames of reference but rather more closely approximate analytic categories that are rarely invoked by performers and audiences.

12 This association between genre and community is not, of course, unique to Chhattisgarh and has been analyzed in numerous folklore studies (see, for example, Dundes 1983; Claus 1989; Badone 1987). What may be "unique" is the social categorization of genre as an indigenously articulated principle of identification and organization. 
No single Chhattisgarhi term is equivalent to the English-usage term "genre." 13 Thus, in the following chapters, several different English words make reference to a single indigenous genre: festival, ritual, song, narrative. Further, we will also notice that little or no distinction is made between religious/nonreligious, ritual/nonritual genres in the social categorizations of the regional repertoire. Because form and content have been foregrounded in our Western usage of "genre," perhaps in the Chhattisgarhi context "tradition" would more accurately reflect what is meant when the name of a particular performance genre is used. When bhojali festival participants talk about the festival, they rarely articulate a distinction between the rituals they perform and the songs they sing; the entire performance complex is "bhojali". Or, if the girls talk about "seating bhojali" (forming the ritual friendship), the ritual soaking of the goddess and her service through song are implicit in that friendship formation. ${ }^{14}$ However, "tradition," too, has English-language connotations that I do not wish to invoke here, so I have retained "genre" as it has come to be used in contemporary folklore scholarship: a cultural framework for interpretation that sets up certain expectations, orientations, and "interpretive procedures" (Bauman I992b:58).

Recognizing indigenous systems of genre as a source for a folklore community's commentary about its own traditions, then, I have taken the social organization of the Chhattisgarhi repertoire as a point of entry into the analyses of individual genres. A guiding question has been, What does it mean for a particular performance genre to be identified with, to "belong to," for example, unmarried girls, tribal (ädivāsī) castes, or the region itself? With what other genres does this designation put the selected genre into conversation or opposition? What are the interpretive frames constructed by this social organization of genre and the resulting intertextual relationships?

Although these questions have taken shape by listening to Chhattisgarhi conversations, verbal commentaries, and metafolklore-and it is there that I begin to look for their answers-these direct articulations are not "all" that the performer or audience member "knows." Much of what she or he knows about rules of folklore usage, especially the flexibility of those rules, is accessible only through ethnographic observation of performance. ${ }^{15}$ I found Ro-

${ }^{13}$ I was once called on to give a lecture in Hindi on the subject of indigenous genres and drew a blank when I tried to think of a Hindi equivalent for "genre" with the implications that the word holds in Western literary and folklore scholarship. Finally, in desperation I called a Hindi professor at the University of Wisconsin, a linguist and native speaker, who immediately responded with the suggestion "genre."

${ }^{14}$ Gregory Nagy (1994) suggests a similar phenomenon for the genre of epic: "The genre, the set of rules that generate a given speech-act, can equate itself with the occasion, the context of this speech act. To this extent, the occasion is the genre." See also Nagy 1990:362.

${ }^{15}$ I thank Amin Sweeney for his critique (letter to author, May 1987) of my early essay on 
Setting/Event ${ }^{16}$

CONTEXT

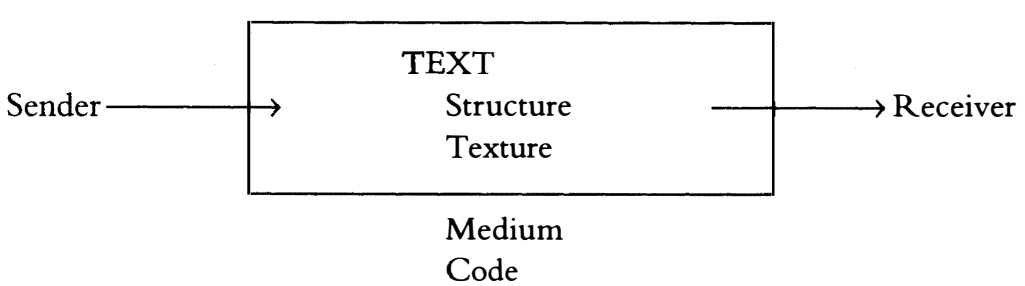

man Jakobson's model for communication (adapted by ethnographers of speaking such as Hymes and others) to be useful in sharpening my own ethnographic observation, identifying units for analysis, and in thinking through the performative implications of the social organization of genre. Jakobson identified key components of the communicative act to be addresser, addressee, context, message, contact, and code (1960). A. K. Ramanujan frequently drew on this model when he served as a discussant for conference folklore panels in the I980s and diagramed it as shown in the schematic. The model sets up the variables of context and text as interdependent components of a system, so that any one of the components may shift depending on the identity or content of any one of the others. The model becomes dynamic, the emergent nature of performance more readily identifiable, when applied to comparative data-the "same" genre performed in two different cultural areas or two settings (for example, Phuljhar and the Raipur plains, or a ritual and nonritual setting), different performances of the same genre observed over a period of time, or the variation of components when two genres from a given repertoire are compared. I base the analyses of the genres chosen for this study, at some level, on such comparative data. ${ }^{17}$

To analyze all the variables of what is identified here as "context," both

the sua $n \bar{a} c$ (1987) that helped me to articulate action itself as a form of indigenous knowledge, as well as commentary about that action.

${ }^{16}$ Charles Briggs distinguishes the "setting/ event" level of context from a broader cultural context with the term "situational context" (I988:I 3).

${ }^{17}$ In a proseminar on folklore methods held at the University of Wisconsin shortly after I returned from my first field study (spring I982), Alan Dundes stated categorically that "the study of folklore is necessarily comparative." At the time, I thought he meant cross-culturally comparative (illustrative in the historic-geographical school of folklore studies); it was only when I began to examine individual performances of the genres I had taped in contrastive settings that I understood that comparison could be on more subtle levels and was able to agree with him. 
cultural and situational, would be not only an ethnographic impossibility, but its attempt would be to throw up a screen of false objectivity (Briggs 1988:13). However, indigenous systems of genres, oral commentary, and performances themselves provide what Briggs has called "contextualization cues" (I988: I 5; see also Goodwin and Duranti I992:4), cues that direct us to those aspects of context that the participants in the performance event themselves foreground. These cues, many of which in Chhattisgarh are articulated through the social identification of the genre, serve as an entry into understanding the textual "interiors" of the performances we will look at in this book.

In chapter 2 I examine a female festival tradition called bhojali that is celebrated in both the Raipur heartland of Chhattisgarh and the Phuljhar periphery. The primary festival participants in Phuljhar are unmarried pubescent girls who form ritual friendships by exchanging the wheat seedlings they worship as the goddess for the duration of the nine-day festival. In the Chhattisgarh heartland, however, the festival is celebrated by married women, who become possessed by the goddess they serve, and the ritual friendships formed are secondary. The differences between the festival as celebrated in the two contexts are so dramatic that participants in the Raipur plains hardly believed my descriptions of what I had seen in Phuljhar only eighty miles away. I examine the implications of the shift in this social identification of genre, the intertextual relationships in which it places bho$j a l i$, and the resulting frames of interpretation created.

Chapter 3 looks at another Phuljhar festival tradition for unmarried girls. Dālkhāi is consistently identified in everyday conversation as a "holi [festival of reversal] for unmarried girls." By the time I began my fieldwork in the fall of I980, the festival was a dying one; I witnessed what I believe to have been the last celebration of dialkhāi in Phuljhar. The song tradition, however, is still creative and vibrant, sung outside the festival context by men and women alike, of all ages. These songs are characterized as "buri git" ("bad," vulgar songs). In my effort to understand the implications of these two characterizations - a festival of reversal for unmarried girls, but one whose songs are "bad"-I began by looking at the shifting frame of the performance contexts, the identities of the singers, as the festival has died. Crucial to my understanding of what the festival may have meant when it "belonged to" unmarried girls is a long sung narrative performed for me by a village wise woman as the "story of the festival," an indigenous commentary that illustrates the subtlety with which "interiors" of texts are understood. Even as the festival context for performance of dälkhāi has been lost, it is retained in cultural memory and continues to inform the interpretation of the genre as it now exists. 
The sua nāc of Chapter 4 is spoken of as a harvest-dance genre performed by $\bar{a}$ divāsi female land laborers in the courtyards of landowners, a performance that transforms the harvested paddy into ritual wealth, the goddess Lakshmi herself. However, it is a genre "claimed" by members of a wide spectrum of social groups within the folklore community as typifying Chhattisgarh. The sūa nāc establishes a temporary performative channel of communication between two social groups for whom such a channel does not normally exist; and the focus of the performance becomes that channel itself-the auspicious dance and its nonverbal, iconographic message. The sung narratives accompanying the dance are also performed outside of the dance context, sung by women to other women of their own class and caste status. I examine the shifts in interpretive frames when the identity of performers and audience shifts in these two contexts. Outside the dance, the communicative channel is assumed to be present, and the focus of the sua nāc performance falls on the sung verbal text, in which the sadness of a young bride's new life in her sasural (home of marriage) is imaged.

The genre of the kathān $\bar{\imath} k \bar{u} h \bar{a}$ of Chapter 5 stands apart from the others I consider because there is no bounded social group with which it is regularly identified. Rather, it is belongs to individual performers who, through their storytelling, mold an audience into a performative community for a few brief hours; the audience is given the active role of "responder" to the kathān $\bar{\imath}$ $k \bar{u} h \bar{a}$. The genre is an example of the space given within the Chhattisgarhi/Phuljhar repertoires for individual creativity. The kathān $\bar{\imath} k \bar{u} h \bar{a}$ is known as a professional storyteller, one who takes folktales normally performed by nonprofessionals in private settings, "joins them one to another," and adapts them for public performance. What distinguishes his performances is not the content of the narratives but the style in which they are told, the ways in which he is able to create and hold an audience. Thus, the focus of this chapter is the performative style of the kathāni kūha.

The regional epic candaini and the Mahabharata performance genre called pandvani are the two genres that have the widest social identity in Chhattisgarh, that is, they are consistently identified with the region itself, rather than by caste, gender, or age. In Chapter 6 I look at what it means for an epic to be so identified by comparing it with the "same" epic tradition as it is performed outside Chhattisgarh, in the northern Gangetic plains, where it is a caste-identified tradition. The regional identity of candain $\bar{\imath}$ and pandvān $\bar{\imath}$ places them in the same generic category within the Chhattisgarhi folklore repertoire; they are regularly spoken of in tandem in indigenous commentary about the repertoire itself. The performances of candaini contribute to the interpretive frames through which performances of pandvāni are received and vice versa. And so in Chapter 7, I consider this relationship, asking what it means for pandvānī to be a Chhattisgarhi genre rather than a Hindi, pan- 
Indian genre such as the Ramayana is perceived to be. When I asked what the difference was between pandvāni and the recently televised serial production of the Mahabharata, one Chhattisgarhi villager answered that the latter was shastric (textual), whereas pandvāni is "sung from our hearts."

The second section of the book is comprised of texts that are translations of two full performances: the Song of Subanbali (Chapter 3) and the kathan $\bar{\imath}$ $k \bar{u} h \bar{a}$ 's performance (Chapter 5). Both typify South Asian performance genres for which full translations are not yet available: long, nonepic narratives. The first translation is of a one-and-one-half-hour performance by a semiprofessional female singer, and the second, a three-hour narrative performed by a professional male storyteller who weaves together discrete folktales, "line by line." My goal has been to provide translations that reflect the oral composition and performance of the texts. I have retained the line integrity of the performance texts; at times this has required a more literal, rather than "smooth," translation. The kathāni kūha s's performance, in particular, catches the ethos of Chhattisgarhi village life and language. Part of this ethos, as mentioned earlier, is the strong and often defiant voice of women, which is heard clearly, but distinctively, in these two performance texts.

If indigenous folklore genres and the principles of their organization within a given repertoire are socially constructed, historically situated frames of production and interpretation, then shifting cultural and historical contexts will affect the shape of those frames and the meanings generated through them. This flexibility and transformation have been addressed for individual genres, where applicable, in their individual analyses. The conclusion of this volume looks more generally at the shifting boundaries of genre identification and classification under the influences of increasing literacy and mass media technologies in Chhattisgarh. These changes have begun to affect the principles of organization within the Chhattisgarhi folklore repertoire, the communities with which certain genres are associated, and thus the ways in which they are interpreted by members of the folklore regional community. Even while the social organization and identification of genre are reconfigured, retaining the principles of Chhattisgarhi indigenous genres, a coexisting system of classification, based primarily on form (song, narrative, dance), is emerging in such contexts as radio and television programming, print media, and folklore festivals and performance competitions. Finally, I return to the Chhattisgarhi principle of social organization of genres to look more closely at the ways in which performance identifies and gives identity to various levels of community: the folklore region that shares a repertoire, the folklore community that shares rules of usage for that repertoire, and the folklore group whose members are the performers themselves. 